\title{
PENTINGNYA BERPIKIR KRITIS DALAM MENYELESAIKAN TAHAPAN PROSES KEPERAWATAN
}

\author{
Kiki Dwi Febriyanti \\ Kiifeb83@gmail.com
}

\section{LATAR BELAKANG}

Peran perawat adalah untuk membantu individu, sakit atau sehat, dalam kinerja aktivitas yang menunjang pada kesehatan dan pemulihannya atau pada kematian yang tenang (International Council of Nurses, 1973). Perawat dalam menjalankan tugasnya menggunakan tahap proses keperawatan agar kerja perawat dapat mencapai nilai yang maksimal. Perawat juga memiliki peranan yang sangat penting dalam keberhasilan keselamatan dan kesehatan pasien. Perawat juga mempunyai peran penting dalam kualitas di rumah sakit yaitu dengan menjaga bio-psiko-sosio dan spiritual pasien. Perawat juga bertugas untuk memberikan asuhan keperawatan kepada pasien dan keluarga.

Berpikir kritis sangatlah diperlukan saat ini, terutama dalam keperawatan karena kita dituntut untuk tegas dan tanggap kepada pasien kita atau klien bahkan disaat gawat darurat sekalipun.
Sikap bepikir kritis mampu memberikan pelajaran banyak kepada kita salah satunya adalah fokus kepada pikiran dan tindakan yang baik sekalipun kita dituntun untuk berpikir kritis dalam proses apa yang kita lakukan itu semua dilakukan dalam kebaikan bersama sebab manfaat dari berpikir kritis tidak hanya menguntungkan seorang perawat, tapi juga kepada seorang klien atau pasien.

Berpikir kritis merupakan suatu konsep dasar yang terdiri dari proses mental seseorang untuk memperoleh suatu informasi agar proses keperawatan berjalan dengan lancar. Dalam proses keperawatan berpikir kritis penting, maka dari itu agar perawat dapat berpikir kritis harus mempunyai pengetahuan mengenai hal tersebut, salah satunya yaitu model berpikir kritis harus dipelajari dan diterapkan

Berpikir kritis penting dilakukan oleh seorang perawat sebelum mengambil keputusan dalam asuhan keperawatan. Asuhan keperawatan merupakan suatu 
metode ilmiah dalam penyelesaian masalah klien. Kemampuan perawat mengidentifikasi masalah klien dan memilih solusi intervensi yang tepat tidak lepas dari kemampuan berpikir kritis perawat, yaitu kemampuan perawat menggali alasan berdasarkan evidence base dari setiap masalah dan solusi yang teridentifikasi.

Tujuan berpikir kritis kepada perawat yaitu untuk memiliki rasa ingin tahu yang tinggi, dan penting juga bagi pasien dan keluarga pasien karena untuk Asuhan keperawatan yang diberikan kepada pasien dengan tepat, dan untuk menaikkan derajat kesehatan dan menurunkan angka sakit.

\section{METODE}

metode yang digunakan dalam penulisan ini adalah metode kajian bebas dimana metode ini berwilayah lebih sempit dengan tingkat variasi yang rendah, namun dari penulisan ini dapat berkembang menjadi lebih luas. Metode kajian bebas ini merupakan metode yang dilakukan untuk melakukan penulisan yang dikumpulkan dari beberapa sumber seperti buku teks, buku referensi jurnal dan e-book, dan juga dibandingkan dengan jurnal yang berhubungan dengan "pentingnya berpikir kritis dalam menyelesaikan tahapan proses keperawatan". Sehingga pembaca dapat mengerti informasi yang sudah ditulis dan dapat memahami pentingnya berpingnya berpikir kritis dalam menyelesaikan tahapan proses keperawatan.

\section{HASIL}

Hasil penulisan ini meliputi gambaran tentang pentingnya berpikir kritis bagi seorang perawat dalam meyelesaikan tahapan proses keperawatan. Hasil ini menunjukkan bahwa pemikiran kritis ini sangat penting bagi perawat maupun pasien. Didalamnya kita dapat mengetahui manfat berpikir kritis dalam proses keperawatan.

Sebagai perawat professional, perawat harus selalu melihat dan berpikir kedepan. Perawat tidak dapat membiarkan berpikir menjadi sesuatu yang rutin dan standar. Praktik keperawatan harus selalu berubah. Sehingga dapat dikatakan, dengan tersedianya pengetahuan baru, perawat professional harus selalu menantang caracara tradisional dalam melakukan sesuatu dan mencari apa yang paling efektif, yang mempunyai bukti-bukti mendukung secara ilmiah, dan memberikan hasil yang lebih baik untuk klien. Untuk berpikir secara kritis membuat perawat mampu belajar dan untuk secara positif mempengaruhi praktik keperawatan (Potter \& Perry, 2005). 
Proses keperawatan merupakan suatu pendekatan untuk pemecahan masalah yang mendukung kemampuan perawat untuk mengatur dan memberikan asuhan keperawatan yang baik dan benar bagi klien. Dimana dalam memberikan asuhan keperawatan akan dilakukan pengkajian, menentukan diagnosis, merencanakan tindakan yang akan dilakukan, melaksanakan tindakan serta mengevaluasi hasil asuhan yang telah diberikan dengan berfokus pada klien / pasien. Tujuan dari proses keperawatan yakni dalam memecahkan suatu permasalahan, mengguakan standar untuk praktik keperawatan, memperoleh metode yang dapat dipakai dalam segala situasi serta meningkatkan asuhan keperawatan yang berkualitas.

Dalam penerapan berpikir kritis dalam pola berpikir kritis terbagi menjadi 3 tingkatan yaitu pemikiran kritis dasar, pemikiran kritis kompleks, dan pemikiran kritis komitmen. Contohnya dengan memperhatikan kebutuhan pasien dengan seksama, meningkatkan kepekaan terhadap keluhan pasien seperti keluhan nyeri dan menanyakan bagaimana perasaan yang sedang di alami pasien sehingga perawat dapat berpikir kritis dalam melakukan tahapan proses keperawatan selanjutnya yang akan diberikan kepada pasien, tanpa pasien mengeluh terlebih dahulu hal itu dapat meningkatkan rasa nyaman pada pasien.

\section{PEMBAHASAN}

Berpikir kritis merupakan sebuah proses. Proses berpikir ini bermuara pada tujuan akhir yang membuat kesimpulan ataupun keputusan yang masuk akal tentang apa yang harus kita percayai dan tindakan apa yang akan di lakukan. Berpikir kritis bukanlah dilakukan untuk mencari jawaban semata, tetapi yang terlebih utama adalah mempertanyakan jawaban, fakta, atau informasi yang ada. Dengan demikian bisa ditemukan alternatif atau solusi terbaiknya. Berpikir kritis sangat penting untuk dilakukan karena untuk berbagai manfaat yang bisa kita ambil atau kita petik dari proses ini. Kualitas keputusan, Kualitas berpikir kritis yang kita terapkan akan mempengaruhi kualitas hasil akhir dari tindakan kita yang didahului dengan proses berpikir kritis tersebut (Simamora, 2019).

Berpikir kritis yaitu sebuah proses dimana perawat akan menggunakan informasi sebagai pertimbangan untuk membuat kesimpulan. Tujuan awal berpikir kritis adalah untuk mengungkapkan kebenaran dengan menyingkirkan semua yang salah, supaya kebenaran akan terlihat. Sebagai perawat professional, perawat harus selalu 
berpikir jangka panjang. Oleh karena itu, berpikir kritis di dalam keperawatan, pelaksanaan dan evaluasi keperawatan pada filosofi keperawatan, terdapat tiga unsur yang menjadi proses berpikir dalam mengembangkan ilmu keperawatan, yaitu care, holism, dan humanism. Dalam argumentasi dan dalam cara berpikir, kita ingin bergerak maju dan mendapat suatu hal yang baru.

Kemampuan berpikir kritis tumbuh ketika seseorang memperoleh pengetahuan baru didalam praktik keperawatan. Individu yang berfikir kritis memiliki perilaku yang percaya diri,rasa ingin tahu yang tinggi, tanggung jawab dan otoritas, mau mengambil resiko, disiplin, kreatif dan integritas. Fungsi Berpikir Kritis dalam keperawatan adalah memberikan analisa kasus dan merumuskan masalah keperawatan dengan akurat dan tepat, Pemanfaatan proses berfikir kritis dalam aktivitas keperawatan sehari-hari. Mencari alasan yang relevan terhadap nilai keputusan dan menemukan alasan yang logis atas dasar keputusan yang diambil.

Menurut $\quad$ Paul(1993) dalam Potter\&Perry(2009), Perawat yang berpikir kritis akan memiliki perilaku yang percaya diri. Berpikir independen, memiliki rasa igin tahu yang tinggi, mau mengambul resiko, disiplin, kreatif, berintegritas dan adil. Contoh aplikasi dari perilaku berpikir kritis percaya diri adalah perawat belajar bagaimana memperkenalkan dirinya sebagai perawat kepada klien dan berbicara penuh percaya diri saat memulai asuhan keperawatan.

Kataoka-yahiro dan saylor mengembangkan model berpikir kritis yang terdiri atas tiga tingkat pemikiran kritis, yakni : dasar, kompleks, dan komitmen. Sebagai pemula, individu akan menerapkan model pemikiran kritis pada tingkat dasar.

\section{Pemikiran kritis dasar}

Pada tahap pemikiran kritis dasar, individu percaya bahwa para ahli memiliki jawaban yang tepat untuk setiap masalah. Menurut Kataoka Yahiro-dan Saylor(1994) dalam Potter\&Perry(2009)Pemikiran kritis dasar adalah tahap awal untuk mengembangkan sebuah pernyataan / penjelasan. Individu pemikir kritis pada tingkat dasar akan belajar menerima berbagai pendapat individu yang tidak memiliki pengetahuan yang cukup. Pengalaman yang kurang, serta tidak percaya diri akan mengurangi kemampuan untuk berpindah ke tingkatan pemikiran kritis kompleks. Agar individu dapat meningkatkan kemampuan berpikir kritis, maka individu harus meningkatkan 
kepercayaan dirinya untuk dapat naik ke tingkat selanjutnya.

2. Pemikiran kritis dasar

Pemikiran kritis kompleks yaitu individu akan dapat menganalisis dan memeriksa beberapa pilihan dengan lebih independen. Individu akan memisahkan dirinya dari sebuah aturan. Kemampuan berpikir dengan pandangan yang luas dan keinginan untuk mencari informasi tentang pendapat para ahli akan mulai terbentuk. Pada tahap pemikiran kritis kompleks, individu akan dihadapkan pada pilihan yang memiliki keuntungan dan resiko masing-masing dari pilihannya, oleh sebab itu untuk menentukan sebuah keputusan akhir harus memikirkan dengan hati-hati resiko dan keputusan yang akan diambil.

3. Pemikiran kritis komitmen

Pada tingkat komitmen atau tingkat akhir, individu dapat mengantisipasi untuk menentukan sebuah pilihan tanpa bantuan dari orang di sekitarnya.Artinya, individu harus mempertanggungjawabkan setiap keputusan yang diambilnya.Di tingkat ini, individu tidak hanya mempertimbangkan sebuah pilihan kompleks pada sebuah masalah / kasus. Namun individu juga harus mempertimbangkan pilihan-pilihan lain yang dapat dijadikan sebagai pemecahan masalah atau pilihan lain sebagai pendukung dari pilihan kompleks.

Asuhan keperawatan adalah suatu proses atau rangkaian kegiatan pada praktik keperawatan yang langsung diberikan kepada klien dalam berbagai tatanan pelayanan kesehatan. Tujuan pemberian asuhan keperawatan :

○ Meningkatkan kesehatan klien

- Mencegah timbulnya penyakit pada klien

- Menyembuhkan penyakit klien

- Pemulihan kesehatan klien, dan

○ Pemeliharaan kesehatan klien.

Tujuan pemberian asuhan keperawatan ini dapat dicapai dengan adanya penekanan pada upaya pelayanan kesehatan, terutama dalam mencapai kemampuan manusia untuk

hidup sehat dan produktif (Hutahaean, 2010).

Tahapan proses keperawatan adalah proses kompleks yang menggunakan pendekatan sistematik yang bekerja sama dengan keluarga dan individu sebagai anggota keluarga. Berikut tahapan dari proses keperawatan meliputi:

1. Pengkajian

Pengkajian merupakan upaya mengumpulkan data secara lengkap dan sistematik untuk dikaji dan 
dianalisa sehingga masalah kesehatan dan keperawatan yang di hadapi pasien baik fisik, mental, sosial maupun spiritual dapat ditentukan. tahap ini mencakup tiga kegiatan, yaitu Pengumpulan data, Analisis data dan Penentuan masalah kesehatan serta keperawatan.
a. Pengumpulan data
b. Analisa data
c. Perumusan masalah

2. Diagnosa keperawatan

Diagnosa keperawatan memberikan dasar-dasar pemilihan intervensi untuk mencapai hasil yang menjadi tanggung gugat perawat melalui keputusan klinis mengenai sesorang, keluarga atau masyarakat sebagai akibat dari masalah-masalah kesehatan/proses kehidupan yang actual atau risiko.

3. Perencanaan

Perencanaan merupakan tahap yang sistematis dari proses keperawatan meliputi kegiatan pembuatan keputusan dan pemecahan masalah. Dalam perencanaan keperawatan, perawat menetapkannya berdasarkan hasil pengumpulan data dan rumusan diagnose keperawatan yang merupakan petunjuk dalam membuat tujuan dan asuhan keperawatan untuk mencegah, menurunkan, atau mengeliminasi masalah kesehata klien.

4. Implementasi
Implementasi keperawatan adalah serngkaian kegiatan yang dilakukan oleh perawat untuk membntu klien dari masalah status kesehatan yang lebih baik yang menggambarkan kriteria hasil yang diharapkan(Gordon, 1994, dalam Potter\&Perry,1997). Ukuran intervensi yang diberikan kepada klien terkait dengan dukungan, pengobatan, tindakan untuk memperbaiki kondisi, pendidikan untuk klien keluarga, atau tindakan untuk mencegah masalah kesehatan yang muncul dikemudian hari.

5. Evaluasi

Didalam tahap-tahap proses keperawatan, evaluasi dilakukan sepanjang pelaksanaan proses keperawatan(Alfaro,LeFevre, 1998). Evaluasi dalam keperawatan merupakan kegiatan dalam menilai tindakan keperawatan yang telah ditentukan, untuk mengetahui pemenuhan kebutuhan klien secara optmal dan mengukur hasil dari proses keperawatan.

Berpikir kritis sangat penting bagi perawat maupun bagi pasien dan keluarga pasien. Tujuan atau manfaat berpikir kritis bagi perawat sendiri ini memiliki rasa ingin tahu yang tinggi, dan kenapa perawat harus berpikir kritis? Karena setiap saat perawat harus mengambil keputusan, yaitu menggunakan keterampilan 
berpikir dalam asuhan keperawatan.

Dan tujuan untuk pasien ini yaitu untuk menaikkan derajat kesehatan dan menurunkan angka sakit, dengan Asuhan keperawatan yang diberikan kepada pasien dengan tepat.

\section{PENUTUP}

\section{Kesimpulan}

Dalam melakukan suatu tindakan proses keperawatan, perawat di tuntut untuk berpikir kritis karena sangat dibutuhkan dan lebih berpengaruh dalam melakukan suatu tindakan untuk keselamatan pasien di bandingkan dengan perawat yang kurang berpikir kritis. Ada pengaruh berpikir kritis terhadap kemampuan perawat dalam melakukan proses keperawatan dan perawat yang berpikir kritis berpeluang mampu melakukan proses keperawatan dengan baik jika dibandingkan dengan perawat yang kurang berpikir kritis. Tahapan dalam proses keperawatan ialah pengkajian, daignosa keperawatan, perencanaan, implementasi atau pelaksanaan, dan evaluasi. Oleh karena itu, untuk mencapai kualitas asuhan keperawatan yang baik maka diperlukan tahapan proses keperawatan yang sistematis untuk memberikan asuhan keperawatan yang berkualitas.

\section{Saran}

Hasil dari penulisan ini menyarankan tentang pentingnya berpikir krtitis dalam menyelesaikan tahapan proses keperawatan yang meliputi pengkajian, diagnose keperawatan, perencanaan, implementasi atau pelaksanaan, dan evaluasi. Sehingga tututan dari pasien yang dilakukan oleh perawat akan dinilai baik dan dapat meningkatkan kualitas dari asuhan keperawatan itu sendiri. 


\section{DAFTAR PUSTAKA}

Budiono, Sumirah. 2016. Konsep Dasar

Keperawatan. Jakarta : Bumi Medika

Christiana, Y. (2019). LITERATURE

REVIEW

PERENCANAAN

DALAM

PROSES

KEPERAWATAN.

Deniati. K., Anugrahwati, R \& Sumiarti,

T. (2018). Pengaruh Berpikir

Kritis Terhadap Kemampuan

Perawat Pelaksana dalam

Melakukan Asuhan Keperawatan

di Rumah Sakit Hermina Bekasi

Tahun 2016. Jurnal Holistik

Kesehatan. 12 (1):21-22

Ginting, G. K. A. (2019). HUBUNGAN BERPIKIR KRITIS DENGAN KINERJA PERAWAT DI RUMAH SAKIT.

Harahap, N. M. (2019). Peningkatan Kemampuan Berpikir Kritis Mahasiswa Dalam Asuhan Keperawatan. Osf. Io.

Nazvia, N., Loekqijana, A., \& Kurniawati, J. (2014). Faktor yang mempengaruhi kepatuhan pelaksanaan SOP asuhan keperawatan di ICU-ICCU RSUD Gambiran Kota Kediri. Jurnal Kedokteran Brawijaya,28(1), 2125.
Patmawati, T.A, Saleh, A, \& Syahrul, S. (2018). Efektifitas Metode Pembelajaran Klinik Terhadap Kemampuan Berpikir Kritis \& Kepercayaan Diri Mahasiswa Keperawatan. Jurnal Keperawatan Muhammadiyah. 3(2) : 89-92

Simamora, R. H. (2019). Development of Guidelines for Applying appropriate Patient Identification to Achieve Patient Safety Goal INC2019 12th International Nursing Conference. 2019.10455 455 (1 pages)UCI(KEPA) : I410ECN-0101-2019-512-001224337

Simamora. R. H. (2008)The correlation of ward chief's giving direction and command and the performance of on-duty nurses at Jember dr. Subandi general hospital inpatient wards. Jurnal Administrasi dan Kebijakan Kesehatan, (https://fkm.unair.ac.id/jurnal$\underline{\text { administr) }}$

Safitri, R. (2019). HUBUNGAN BERFIKIR KRITIS DENGAN PROSES KEPERAWATAN.

Setiani. (2018). Petanggung jawaban Hukum perawat Dalam Hal Pemenuhan Kewajiban Dan Kode Etik Dalam Praktif Keperawatan. Jurnal llmiah Keperawatan Indonesia. Volume 8. 
Susanto, R. (2010). Penerapan Standar Proses Keperawatan di Puskesmas Rawat Inap Cilacap. Jurnal Keperawatan Soedirman, 5(2), 8084.

Sutriyanti, Y., \& Mulyadi, M. (2019). Analisis Faktor-Faktor yang Mempengaruhi Penerapan Berpikir Kritis Perawat dalam Melaksanakan Asuhan Keperawatan di Rumah
Sakit. Jurnal

Keperawatan Raflesia, 1(1), 21-32.

Tari, C. (2019). Pentinngnya Pengaplikasian Berpikir Kritis bagi Perawat di IGD. Osf.io

Yeni, F. (2014). Pengaruh Pelatihan Proses Keperawatan terhadap Dokumentasi Asuhan Keperawatan di Puskesmas Kabupaten Agam Propinsi Sumatera Barat. NERS Jurnal Keperawatan, 10(1), 24-31. 